\title{
EMORY HOLLOWAY'S FINAL WORD ON WHITMAN'S SON
}

\author{
JOANN P. KRIEG
}

In 1960 Emory Holloway, whose earlier Whitman: An Interpretation in Narrative received the 1926 Pulitzer Prize for biography, published Free and Lonesome Heart: The Secret of Walt Whitman, a work which scholars have (mercifully) forgotten and most have forgiven. The book purported to reveal the identity of one of the six children Whitman claimed (in an 1890 letter to John Addington Symonds) to have fathered. One still feels something of a shock at opening Free and Lonesome Heart and seeing the frontispiece of a young man identified as "John Whitman Wilder, Son of Walt Whitman." Almost immediately after publication, the book's major claim was all but demolished by Charles E. Feinberg who, with a bit of a flourish, produced a contradictory piece of evidence, the existence of which had been kept from Holloway.

Deeply hurt by this belated presentation, Holloway bided his time awaiting an opportunity to defend himself and his theory. But the opportunity never came, and his defense remains outlined and unpublished in a series of letters to one of the few reviewers who took the work seriously, Verne Dyson. I offer the following, based on these letters, not to demean in any way the memory of this wonderful scholar who gave us The Uncollected Poetry and Prose of Walt Whitman, but for these reasons: first, to demonstrate the absolute faith Holloway had in his claim; second, to allow him, posthumously, the opportunity denied him in life to defend himself; and last, as a reminder, especially to those who today invest so much of themselves and their scholarship in theories having to do with the poet's sexuality, of how easily one can be led into placing undue emphasis on one aspect of the totality that was Walt Whitman.

The "secret" referred to in the title of the 1960 book was not, in fact, the existence of John Whitman Wilder or his relationship to Walt, but rather the revelation of what the book jacket describes as "the poet's emotional type." Defining this "type" had been the object of Holloway's scholarship for some eighteen years and was his main purpose in writing the book. While he does not say it quite so unequivocally there, privately he stated his hope that the Wilder business "does not distract attention from my main thesis, namely that Walt was far more normal than some would have it, that he struggled successfully against his ambivalence and that his poetry is the richer, more human, as a result" (Letter to Dyson, June 13, 1960). The key word, of course, is 
"normal," and it was Holloway's overriding desire to locate Whitman within the range of heterosexual "normalcy" that kept him searching all those years for the poet's illegitimate progeny.

In 1955 he thought he had found real traces of one such offspring when Gay Wilson Allen turned over to him a letter that offered information about a son of Walt Whitman. Written in response to Malcolm Cowley's review of Allen's The Solitary Singer, the letter, from a Ruth L. Greene of Pittsford, New York, told of a boy by the name of John Whitman Wilder-"the illegitimate son of Walt Whitman"-who had been raised in Brooklyn by two maiden ladies of the surname Wilder. She suggested a search of the Brooklyn City Directory for verification of the Wilder sisters' residence. This line of inquiry turned up an address for one of the sisters, Mary Alice Wilder, an artist, and for her brother, Victor Wilder, whose son resided in upstate New York. Following these leads, Holloway found John Wilder's grave in Warwick, New York, and received the gift of a photo of John at 12, the same photo that became the frontispiece of Free and Lonesome Heart.

There, so far as Holloway was concerned, was the proof that Whitman was "normal" and that the New Orleans octoroon-of whom Holloway had written so fancifully (and without the benefit of footnotes) in his 1926 biography-might truly have existed, might have been, in fact, but one of many such amours the poet enjoyed. The face that looked back at him from the photo must have eradicated, finally, what was doubtless the shock of finding the original manuscript of "Once I Pass'd through a Populous City," with its reference to "the man who wandered with me, there, for love of me" and which, for a time, had shaken Holloway's faith in the New Orleans romance. ${ }^{1}$

Unable to find a publisher for the new work (Knopf had published the 1926 biography), Holloway guaranteed the cost of publication to Vantage Press of New York City. Charles Feinberg offered to enclose a circular advertising the book in the next issue of the Walt Whitman Review. Publication was set for the end of May, to coincide with the poet's birthday. No sooner was the book out, though, than a bombshell went off and from a source close to the author. Feinberg produced a letter from his Whitman collection which he claimed proved that John Whitman Wilder was one of the twin sons born in 1868 to the prostitute widow of Walt's brother Andrew Jackson Whitman, who died in December of 1863 . The letter was written by a Mrs. H. A. Wilder, supposedly the mother of the Alice Wilder mentioned in the Greene letter which was the source for Holloway's claim. Dated December 7, 1892, the letter came from the Brooklyn address known to have been the home of the Wilder family. Because, unlike the Greene letter, this missive is not included in Holloway's book, it is quoted here in its 
entirety, mispellings intact:

Dec 7th 1892

265 Berkeley Place

Perhaps Mr Whitman remembers my daughter took a little Boy Jack Whitman your Nephew some eighteen years ago from "Ann Whitman" the widow of your Brother "Andrew Whitman" who gave Him to Her to educate \& bring up-a few weeks since the Boy-now calld "Jack W. Wilder," called at your house in Camden but found you too ill to see Him $\mathrm{He}$ is now twenty-three yrs working in the Law office as has [?] a few Weeks since. I wite this to say, the Boy would be vy [very] much pleased if you should see fit to leave him in your will a Picture of yourself \& some of your Books the Books of your own writings - He feels too modest to ask this - Therefore I ask for Him \& trust you may consider my request as coming from Him. Thanking you for all the good your works have done for us all I am most sincerely Mrs. H. A. Wilder ${ }^{2}$

No public word issued from Emory Holloway or from Vantage Press, and those reviewers who chose to notice the book went about their business according to their own lights. One reviewer, Verne Dyson, president of the Walt Whitman Birthplace Association at Huntington, New York, and editor of the birthplace Bulletin, wrote to Holloway seeking clarification. His request initiated a series of four letters written between June of 1960 and January of 1961 in which Holloway set forth his side of the controversy, all of which, he explained to Dyson, he fully intended to include in a second printing of Free and Lonesome Heart. Since that printing never materialized, the letters remain his only statement on a matter which he claimed "affects my responsibility as a scholar ... and the validity of the conclusions reached in my book" (June 13, 1960). ${ }^{3}$

In June, Holloway expressed surprise that the new document had appeared so quickly after publication of his book, and he is "doubly surprised that it came from Mr. Feinberg": "I knew he did not think Whitman had sex relations with anybody and so would read my book from his own angle; but I had had lunch with him . . . a week or so before the book came from the press and he said nothing about this letter though I showed him photographs of John Wilder and of his grave" (June 13, 1960). According to Holloway, Feinberg claimed never to have heard the name Wilder mentioned at that time, but as soon as he had the book in hand he offered what he believed was contradictory evidence. Holloway bravely responded that "a man who walks away from a fact is no scholar," but he insisted to Dyson that John Wilder could not possibly have been Andrew Whitman's son. At this point he said nothing of the possibility that he might have been Nancy Whitman's illegitimate child. As to his lack of prepublication knowledge of the Wilder letter, Holloway claimed never to have known that Feinberg had collected some 1500 letters written to Whitman. He assumed that 
Gay Allen also knew nothing of the letter since "we have always kept in friendly touch," and it was Allen who had turned the Greene letter over to him.

As to the particulars of the Wilder letter, Holloway told Dyson he had asked Feinberg if he possessed the envelope, which Feinberg did not. Feinberg attributed the letter to either the Alfred F. Goldsmith collection or the Horace Traubel collection, one of "a batch of letters addressed to Whitman." Holloway pointed out that there was no salutation, though he had to admit the contents of the letter indicated the intended recipient must have been Walt. In an attempt to determine if the letter was a forgery, Holloway said he asked the surviving Wilder, in upstate New York, if he could supply a specimen of his grandmother's handwriting, which proved impossible. Holloway noted that it was incongruous that a woman who came from a good family would produce a letter of such "uneducated" quality, and he pointed out that the unmistakable letters "H. A." were not the initials of Mrs. Mariner Ayers Wilder (nee Mary Philbrick Stevens). His strongest point concerned the letter's date-more than seven months after Whitman's death. Holloway also took issue with the letter writer's reference to John Wilder as Whitman's nephew:

If John was one of the twins born to Nancy the streetwalker, he was not Walt's nephew, though he could have been his son. I do not wish to say that I believe he was, but he could have been. . . . This much is clear, however, on the face of the letter itself. Mrs. Wilder requests a favor for John on the basis of family relationship. He is not Walt's nephew and the only other relationship would be that of a son. Of course the letter may have used the word "nephew" to mean the illegitimate son of a widow of a brother, but it is as easy to suppose that if Walt is expected to "remember" the Wilders taking John into their family eighteen years before, and if this was done because it was desired to provide him with apparent legitimacy by telling the world he was the son of a married man, Walt's brother, so as to preserve the Whitman name and yet preserve status, then the wording of the letter could have been designed to throw strangers off the track, should the very ill old poet not destroy it before he died; yet he would understand that in reality the letter was a request to leave something to a son. . . .

Despite this theorizing, Holloway declared his unwillingness to accept the letter as proof of any theory until it was corroborated to his satisfaction; apparently, it never was.

Dyson had been considerate enough to seek Holloway's explanation of the controversy before reviewing his book in the July 1960 issue of the Walt Whitman Birthplace Bulletin (Volume 3, no. 4, 3-8). John Ciardi was not so considerate. In the Saturday Review of June 26 he caustically dismissed Holloway's claim that John Wilder was Whitman's son as "the willful piecing together of circumstantial evidence." Pleading lack of knowledge of the "minutiae" of Whitman's life, Ciardi claimed he called Charles Feinberg to inquire if the collector had any unpublished documents on John Whitman Wilder. Whether that is how 
it happened, or if Feinberg called him, is not known; Ciardi may also have heard rumors of the letter which Feinberg had made known to Holloway postpublication. In any case, Ciardi's review included not only a transcript of the letter, but a reproduction of the original. After laying out the facts, Ciardi concludes, "The weight of all contemporary evidence, therefore, firmly establishes that John Whitman Wilder was one of the twins born to Nancy Ann Wilder [he means Whitman, for he later refers to her by that name] in 1868 . Unless we are to entertain the assumption (and Holloway himself would certainly reject it in dismay) that Walt Whitman begot twins by his brother's widow, the only possible relationship that can be established between the poet and John Whitman Wilder is that Nancy Ann Whitman took advantage of her late husband's relationship to pass the boy off as Walt Whitman's 'nephew." "4 Little did Ciardi know to what lengths the scholar was prepared to go to prove Whitman "normal," if only to himself.

Holloway did not see the Ciardi review when it appeared because he was at his summer home in Maine, but he learned of it from a friend. On July 4, 1960, he wrote Verne Dyson:

Ciardi is always in some controversy or other, and the very fact that he takes a strong position is likely, I think, to produce two results: those who oppose him by habit will be provoked to at least mental reply, and both those who follow him and those who can't stand the "new critics" will feel that they have to read the book to keep up with a Ciardi conversation piece.

In this same letter he insisted he did not blame Feinberg for the manner in which the Wilder letter was produced, but in an added handwritten postscript he questioned Feinberg's scholarship and said he had written to him arguing that the letter "tended to corroborate rather than to disprove my general thesis." Since the general thesis of the book had to do with proving Whitman's heterosexuality, this would indicate Holloway's conviction that the poet had produced twins by his erstwhile sister-in-law. Indeed, the postscript begins by saying that the friend who conveyed news of the Ciardi review had pointed out that if such were the case, "it wouldn't be the first time (See Scripture)." "I had thought that too," Holloway says, adding "But proof?"

There is no reference in the Holloway/Dyson correspondence to the review of Free and Lonesome Heart by C. Carroll Hollis that appeared in Walt Whitman Review (June 1960). While Holloway explained his lack of access to the Saturday Review by saying that the local library in Meddybemps, Maine had dropped its subscription for lack of reader interest, it is hard to believe that he did not himself subscribe to the Walt Whitman Review, or that he would not have seen the June issue before leaving for his vacation retreat at the end of that month. Perhaps the close relationship of Charles Feinberg to the Review accounted for 
his silence, for while Ciardi was an outsider to Whitman scholarship Hollis was not, and what was said in the Review may have been too painful for comment. Yet the review was not unkind, only truthful, registering regret that the offending chapter on John Whitman Wilder had not been published first as an article so that it might "have called forth from other Whitman scholars additional material in support of or in opposition to the claim." One wonders if Hollis was aware of the lunch Holloway shared with Feinberg when, apparently, no offer of additional material was made.

In his review, Hollis lays out the facts of the letter, and opines that Holloway had been confirmed in his belief concerning Whitman's sexuality because of his annoyance with "psychoanalytical criticism more interested in Leaves of Grass as evidence of Whitman's homosexuality than as poetry." "I can imagine," he continues, "the sense of triumph with which a discovery of a Whitman son would be welcomed," and then adds, "Indeed, on such grounds, I almost wish the story were true, but it is not." With this one statement Hollis places Holloway's entire obsession with Whitman's sexuality in a temporal and philosophical context, making it seem less an idée fixe and more a matter of conventionality.

Holloway was aware of, and grateful for, Verne Dyson's review in the Whitman birthplace Bulletin, which he had seen by August 2, 1960. On that date he wrote to his friend, thanking him for the "generous and gentle treatment" of his book. Dyson may have suggested that Holloway make some answer to the unfavorable reviews, for Holloway explains that he is unaccustomed to responding to reviews, favorable or unfavorable, and now that Dyson had presented enough of the facts to place the Ciardi review in doubt, he need not do so himself. He hoped that Ciardi would see the article, though he doubted it would cause him to "modify his quick judgment or mollify his manner of speaking." $\mathrm{He}$ seemed to hope that others whose opinion he valued would also see Dyson's review, for along with his order for a dozen copies he expressed a desire to know if scholars such as "Miller of the University of Tennessee, Floyd Stovall, Goehdes of North Carolina, Blodgett of Union, and Gay Allen are not on your regular mailing list."

By December of 1960 Holloway was less concerned with the details of the argument, only looking for more reviews, which seemed not to be forthcoming. He was still awaiting a specimen of Mrs. Wilder's handwriting for purposes of comparison with the letter Feinberg had produced, and the new quest for evidence began to take on the aura of the previous search for Whitman's children. By now he was wary, however, and in a typed postscript he informed Dyson that his letter was "Not for publication." 
January of 1961 found Holloway still hopeful for favorable reviews in scholarly journals. He told Dyson of having met Feinberg at the MLA convention at Philadelphia in December of 1960, where the collector told him he had a list of Whitman materials, including the Wilder letter, inherited by Horace Traubel. At home after the meeting, Holloway checked this with the list of literary "leavings" prepared for him by Thomas Harned's secretary. It supposedly listed all of the papers, with indications of what went to which executor, but Holloway did not find any mention of a Wilder letter on the list. "I shall have to go into this further," he told Dyson: "You will understand that when I again break into print on this subject I shall wish to have at hand all I am able to find out for an integrated statement, well considered." Meanwhile, he extended his friend wishes for a good new year, concluding, "For myself, I am happy in being busy, about the 'number of things' Stevenson averred the world to be full of' (January 14, 1961).

Bibliographic sources do not reveal a time when Holloway ever publicly expressed himself on the subject of the Wilder letter, and it is probably best that he did not. Succeeding scholars have chosen to remember the Pulitzer Prize-winning biography, the numerous articles, the edition of Leaves, and the invaluable Uncollected Poetry and Prose rather than Holloway's search for proof of a "normalcy" that may well have existed only as his own hypothetical construct.

Hofstra University

\section{NOTES}

1 See Emory Holloway, "Walt Whitman's Love Affairs," The Dial 49 (November 1920), 473-483.

2 This letter is quoted from a letter of Emory Holloway to Verne Dyson dated June 13, 1960 and is not from the Feinberg Collection. Holloway typed it from a photostat of the original sent to him by Charles Feinberg.

3 All of the letters are contained in the Emory Holloway File in the Walt Whitman Birthplace Association collection.

4 John Ciardi, review of Free and Lonesome Heart, Saturday Review 26 (June 1960), 35-36.

5 C. Carroll Hollis, review of Free and Lonesome Heart, Walt Whitman Review 6 (June 1960), 36-37. 